\title{
Designing the Innovative University Using Australian Business Excellence (ABEF) and the European Foundation for Quality Management (EFQM) to Increase Quality of Human Resource
}

\author{
Rizka Nugraha Pratikna ${ }^{1} \&$ Indra Gamayanto $^{2}$ \\ ${ }^{1}$ Department of Management, Faculty of Economic, Parahyangan Chatolic University, Indonesia \\ ${ }^{2}$ Department of Information System, Faculty of Computer Science, Dian Nuswantoro University, Indonesia \\ Correspondence: Rizka Nugraha Pratikna, Department of Management, Faculty of Economic, 40141, Indonesia. \\ Tel: 62-222-042-004 ext. 190616. E-mail: rizka.nugraha.p@unpar.ac.id
}

Received: May 9, 2018; Accepted: May 18, 2018; Published: June 24, 2018

The research is financed by ATEK FOODS-Suppliers; Parahyangan Catholic University.

\begin{abstract}
In the age of globalization and the ASEAN Economic Community (AEC), Indonesia needs a high quality means in order to improve human resources. The Australian Business Excellence Framework (ABEF) and the European Foundation for Quality Management (EFQM) are two methods that meet our need and have been tested in the world. Both of these methods will greatly help to improve quality in various sectors. This study will focus on how to improve human resources at the University. Moreover, University/education is the front liner, the early fort to state its sovereignty defending, to produce high quality human resources, to create a lot of things that will be the source for the life of the people in the world, not only the national products but also the international one. Furthermore, after the analysis process, it creates a "University Quality Award Framework" (UQAF) which is a basic guide to universities, especially in Indonesia. This framework needs improvement, from now version 1.0, and it is beginning to improve the quality of education in Indonesia. UQAF result of the application framework will produce the high-quality, balance human resources both high knowledge and strong character.
\end{abstract}

Keywords: Australian Business Excellence, the European Foundation For Quality Management, University, Globalization, the ASEAN Economic Community (AEC)

\section{Introduction}

Being ahead was not only to do well and make everything fine, and assume that everything is fine after doing what was his duty, being superior is giving and doing the best to all sides of your life, your organization, and where to contribute to the whole of human life. Ponder that sentence. whether this is an advice ?; a motivation ?; a sentence that has no meaning ?; or just an opening sentence ?. The answer: This is a sentence that defines the meaning of the word "quality" real. The world is increasingly changing, an advance in information technology develops very quickly, and changes so fast that seemed to be no more time. what is the state universities in Indonesia, are sincerely ready to face globalization? it is meant and said: "we are ready, we are ready and everything was ready". The point is: "What is truly ready?". A classic case is going on in University that is: "How to improve and develop the quality in terms of curriculum, teaching techniques, lecturers and much more", Alter says, Systematic power: Good definitions help in organizing concepts, relationships and information related to whatever is being defined (Alter, 2008); for example from American life, Essential to customize students to American life; to integrate students into college life quickly to avoid feelings of alienation. This means a high level of interaction with international students is required to promote retention and an overall positive learning experience (Hegarty, 2014). In Indonesia, education at the university level is still largely unresolved, for example: lecturers are placed in unsuitable position", so it is a problem. This literature study will use Australian Business Excellence Framework (ABEF) and the European Foundation for Quality Management (EFQM) theories to improve the quality contained in the University. Both of these methods can help the learning practice in its period to have high quality process and produce high quality human resources (students), besides as a result of the development of quality, the quantity increase. This study is based on the education system and before we continue the explanation, it is better if we understand the education systems in Indonesia. 


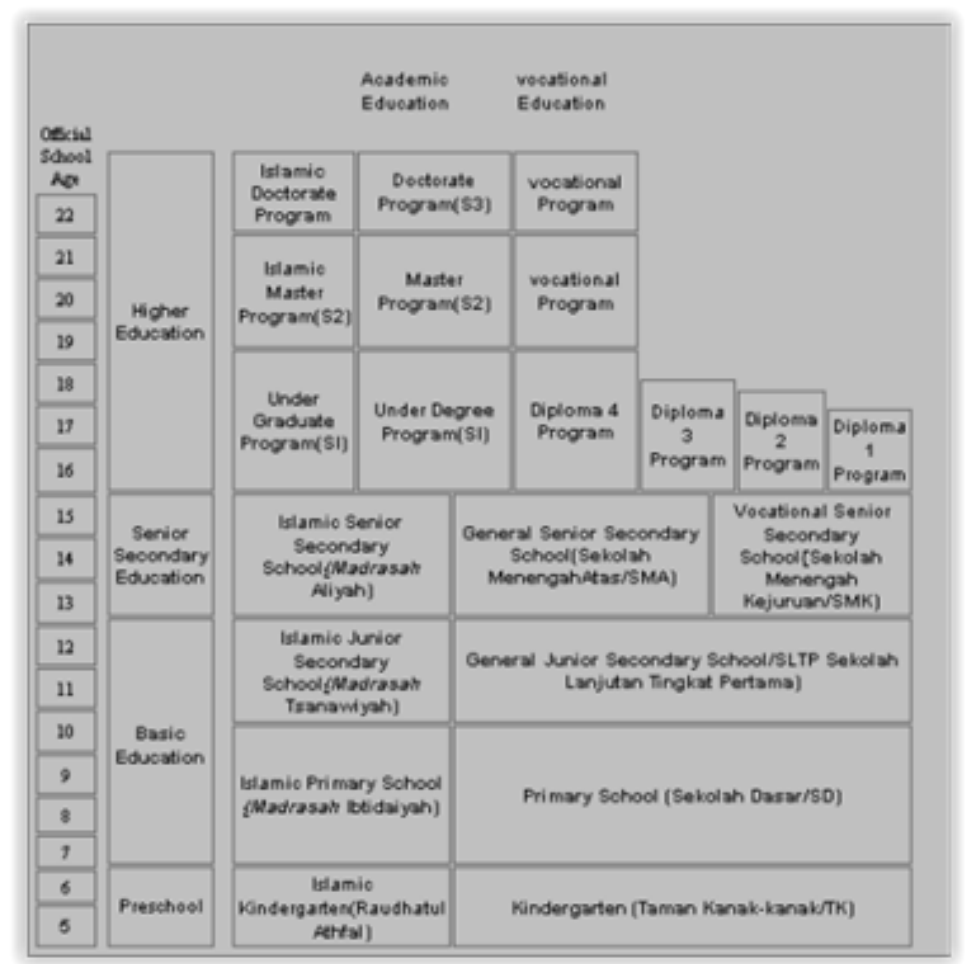

Figure 1. Schools System in Indonesia (Jalal \& Sardjunani, 2005)

Figure 1, explained that the school system in Indonesia starting from Preschool; Basic education; Senior secondary education and Higher education. The title given at the time of completing every education can be seen as follow:



Figure 2. The Indonesian Qualification Framework (IQF) (Megawati Santoso, 2013)

Figure 2 is a stage of education in Indonesia at the time of someone's education ages to the next level and figure 3 explain the title should be earned. Although the education system is running well, human resources generated still needs to be developed, for example the issue of a culture of reading. The literacy rate in Indonesia is still very low, especially in reading text in English, a survey conducted on 546 students, and the result is: 


Indonesian degrees
\begin{tabular}{|l|l|l|}
\hline Type of degree & \multicolumn{1}{|c|}{ Indonesian term } & Equivalent in English-speaking countries \\
\hline Diploma 1 (D1) & Profesional ahli pratama & Associate degree \\
\hline Diploma 2 (D2) & Profesional ahli muda & Associate degree \\
\hline Diploma 3 (D3) & Profesional ahli madya & Associate degree \\
\hline Diploma 4 (D4) & Sarjana sains terapan & Bachelor's degree \\
\hline Sarjana 1 (S1) & Sarjana & Bachelor's degree \\
\hline Sarjana 2 (S2) & Magister & Master's degree \\
\hline Sarjana 3 (S3) & Doktor & Doctoral degree \\
\hline
\end{tabular}

Figure 3. Indonesia Degrees

\begin{tabular}{|llcc}
\hline \multicolumn{4}{c}{ The Amount of Reading Practice } \\
\hline No & \multicolumn{1}{c}{ Description } & Frequency $\left(\sum\right)$ & $\begin{array}{c}\text { Percentage } \\
(\%)\end{array}$ \\
\hline 1 & I read more than five hours every day & 8 & $1.47 \%$ \\
\hline 2 & I read about five hours every day & 2 & $0.37 \%$ \\
\hline 3 & I read about four hours every day & 11 & $2.01 \%$ \\
\hline 4 & I read about three hours every day & 56 & $10.26 \%$ \\
\hline 5 & I read about two hours every day & 95 & $17.40 \%$ \\
\hline 6 & I read about one hour every day & 117 & $21.43 \%$ \\
\hline 7 & I read less than one hour every day & 96 & $17.58 \%$ \\
\hline 8 & I do not always read every day & 122 & $22.34 \%$ \\
\hline 9 & I seldom read & 39 & $7.14 \%$ \\
\hline
\end{tabular}

Figure 4. The Amount Of Reading Practices (Erna Iftanti, 2012)

From Figure 4, No. 8 show that "I do not always read every day" (122 / 22:34\%); No. 6 "I read about one hour every day" (117 / 21:43\%) and No. 7 "I read less than one hour every day" (96/17:58\%). Based on the data, we need a framework to improve the quality of human resources in Indonesia. By combining these two methods, it will be produced: University Quality Award Framework (UQAF), one solution to improve the quality of education in Indonesia. Finally, quoting from Kevin Hogan, The Science of Influence, "Man, like animals, interacting with and responding to the environment far more than we realize on a conscious level. If you want to change your own behavior or someone else, the first thing you can do is to change the environment. Changing environment is very influential matter in changing behavior. Nothing is more powerful than that. Moreover, in this journal, we will first analyze the general system of university using the Australian Business Excellence Framework (ABEF) and the European Quality Award (EFQM) ; the second stage, we will adopt the model proposed by Ernst \& young consulting and apply it to the university system, and the final stage, as a result, is a framework to help universities in Indonesia really have the ability to produce quality human resources.

\section{Method}

Australian Business Excellence Framework and the European Quality Award can be described briefly and clearly as follows: 




Figure 5. Australian Business Excellence Frameworks (SAI Global, 2004)

Australian Business Excellence framework has seven important categories to understand among other things: Leadership; Strategy and planning; Information and knowledge; Person; Customer and market focus; Process, Improvement, and Innovation; Success and Sustainability. The seven categories are intertwined with each other and after analysis, it will be a place will be awarded to the extent to each quality, for example Gold Award; Silver Award, Bronze Award, Excellence Medal.

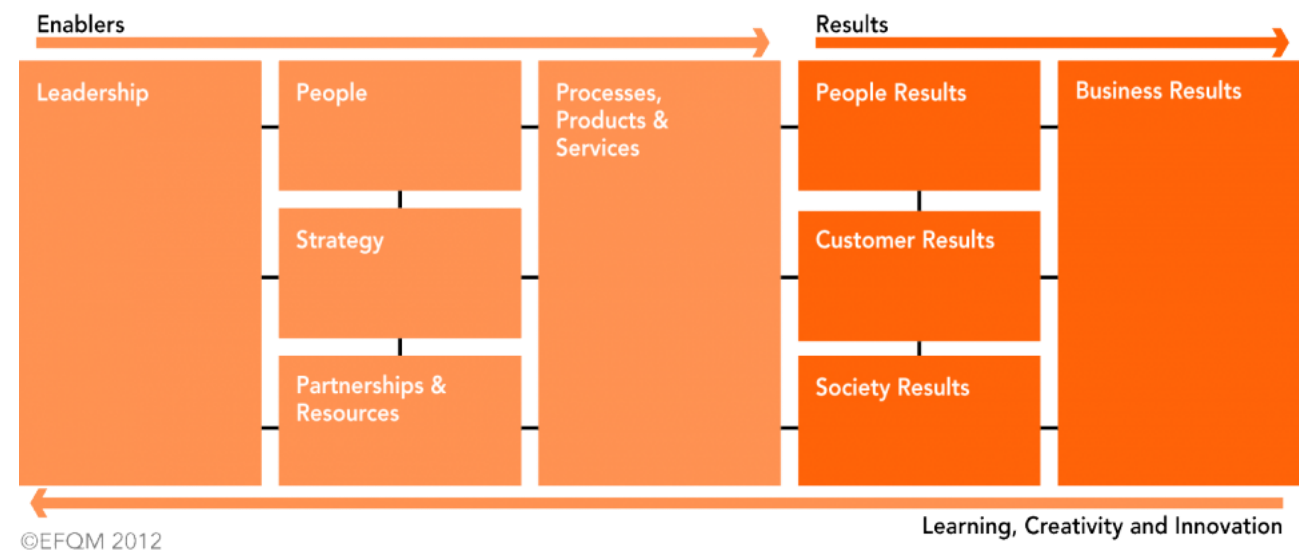

Figure 6. European Foundations for Quality Management (Llusar, Tena, A., Roca-Puig, \& Beltran-Martin, 2009)

While the European Quality Award, there are two important things, namely: What should be done by the organization and how the organization to do so. In this section, there are 5 important enablers to be done, such as Leadership; Person; Strategy; Partnerships and Resources; Processes, Products, and Services. Furthermore, in the next section will define what is to be achieved by the organization or the results includes four things: People Results, Customer Results, Society Results and Business Results. It is possible for both methods of these qualities be applied in several parts in some cases at the university level, because both of these methods have flexibility.

Table 1. Comparison between ABEF \& EFQM 


\begin{tabular}{cc}
\hline $\begin{array}{c}\text { Australian Business Excellence Framework } \\
\text { (ABEF) }\end{array}$ & $\begin{array}{c}\text { European Foundation For Quality Management } \\
\text { (EFQM) }\end{array}$ \\
\hline Leadership & Leadership \\
People & People \\
Strategy \& Planning & Strategy \\
Process Management, Improvement \& & Process, Products \& Services \\
Innovation & Partnerships \& Resources \\
Customers \& Other Stakeholders & Learning, Creativity \& Innovation \\
Information \& Knowledge & Results: People; Customer; Society; Business \\
Results \& Sustainable Performance &
\end{tabular}

From the table above it can be seen that the two methods have significant similarities, so if it is used for the University, the results are as follows:(A) Leadership: It is talking about leadership or the top management that is contained in the University, as the Rector, Vice Rector, Dean, Head of Study Program (Head of Department) and Deputy of Department. (B) People: in this section may include all of the activities within the University, such as faculty, students, the rector, and others. (C) Strategic \& Planning: This is done by the rector who was later executed by Head of Department. (D) Process Management, Improvement \& Innovation - Process, Products \& Services: This section covers the process of teaching and learning within the University and also programs that are owned and innovations made. Customers, Other Stakeholders - Partnership and Resources: This section covers lecturers, students and university cooperation with other universities to develop all the programs that have been established, then in order to obtain information on innovations on programs that already exist in order to survive in Globalization and the ASEAN Economic Community (AEC). (F) Information \& Knowledge - Learning, Creativity \& Innovation: This section is an advanced level of development, where information and all of the existing process, already made to international standards, or minimum national standards so as to give the best to the students. (G) Results \& Sustainable Performance - Results [People-Customer-Society-Business]: This section is the most important part, which determines the result of the ongoing process in the future for the University. Has described the big picture, combined with the two methods with the University and how it is applied. The question is: How do I balance between quality and quantity? It can be explained as follows: Grade point average (GPA) is the quality and quantity is called science and what has been gained during the lecture. So if someone has a GPA of 3:50 but did not master the English language then he has the quality that is the standard of academic quality but does not have the quantity that knowledge to deal with life. What if the opposite? If a have a lower GPA but has a lot of knowledge and experience. This can be illustrated as follows: If a tree is not good, then the fruit produced will not be good as well. So from the fruit, we can get to know the person. Here it is understood that the balance between quality and quantity is a very important factor, not just one of them.

Methods of data collection is using survey method to 100 students, with some questions: (1) Do you master the English very well at the time of graduation; (2) Do you have the desire to read every day and learn what you have learned after the lecture ?; (3) Do you feel ready to face globalization ?. Where the range used is 1-5, 1: no; 2: sometimes; 3 : hesitate; 4: enough master, read a little and quite ready; 5: master; master and ready.

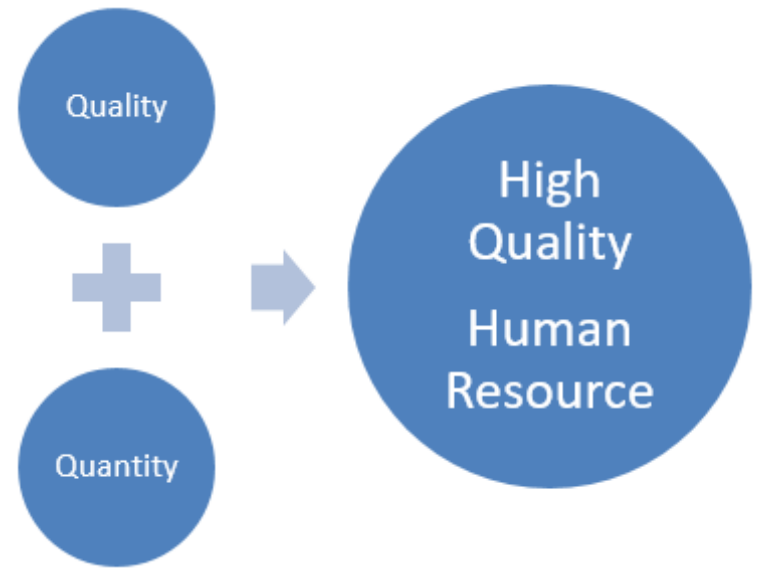

Figure 7. Quality + Quantity $=$ human resources which have high performance 
According to figure 7, quality and quantity must be maintained equally, in order to produce high quality human resources in the face of globalization. The essence of figure 7 , should be able to produce a balance between knowledge and experience, and this should happen within the university, so that human resources can have sufficient skills in the face of competition between countries and globalization.

\section{Results}

Based on the survey data, 60 people chose points 1 and 2 (where: 35 people chose points 1 and 25 chose point 2); 40 people choose points 1,4 and 5 (where, 10 people choose 3 points; 15 people choose 4 points, and 15 people choose 5 points). From these results, we can see that there is still a need for quality improvement so that education and human resources are ready in the face of globalization.

World Bank data, Indonesia skills report, Trends in Skills Demand, Gaps, and Supply in Indonesia (World Bank, 2010), provide data as follows:

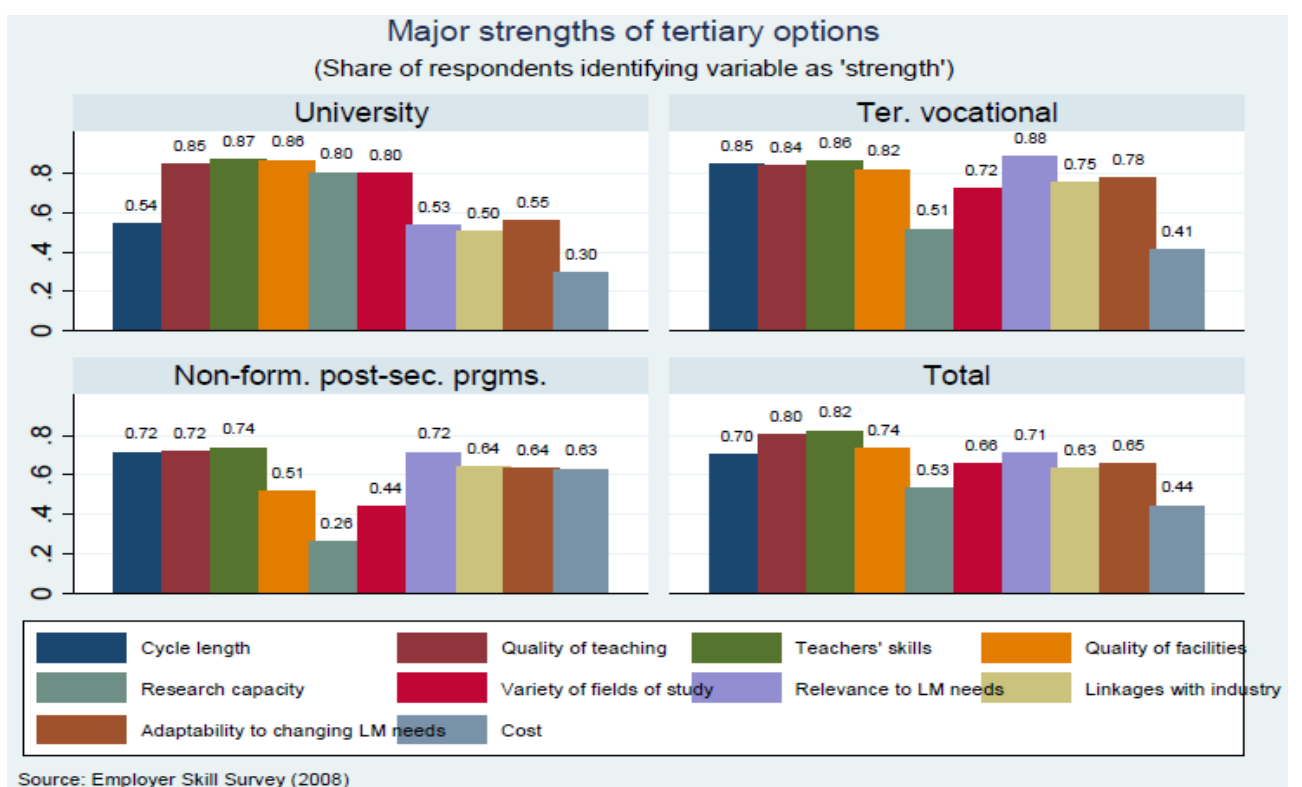

Figure 8. Major strengths of tertiary options (employers)

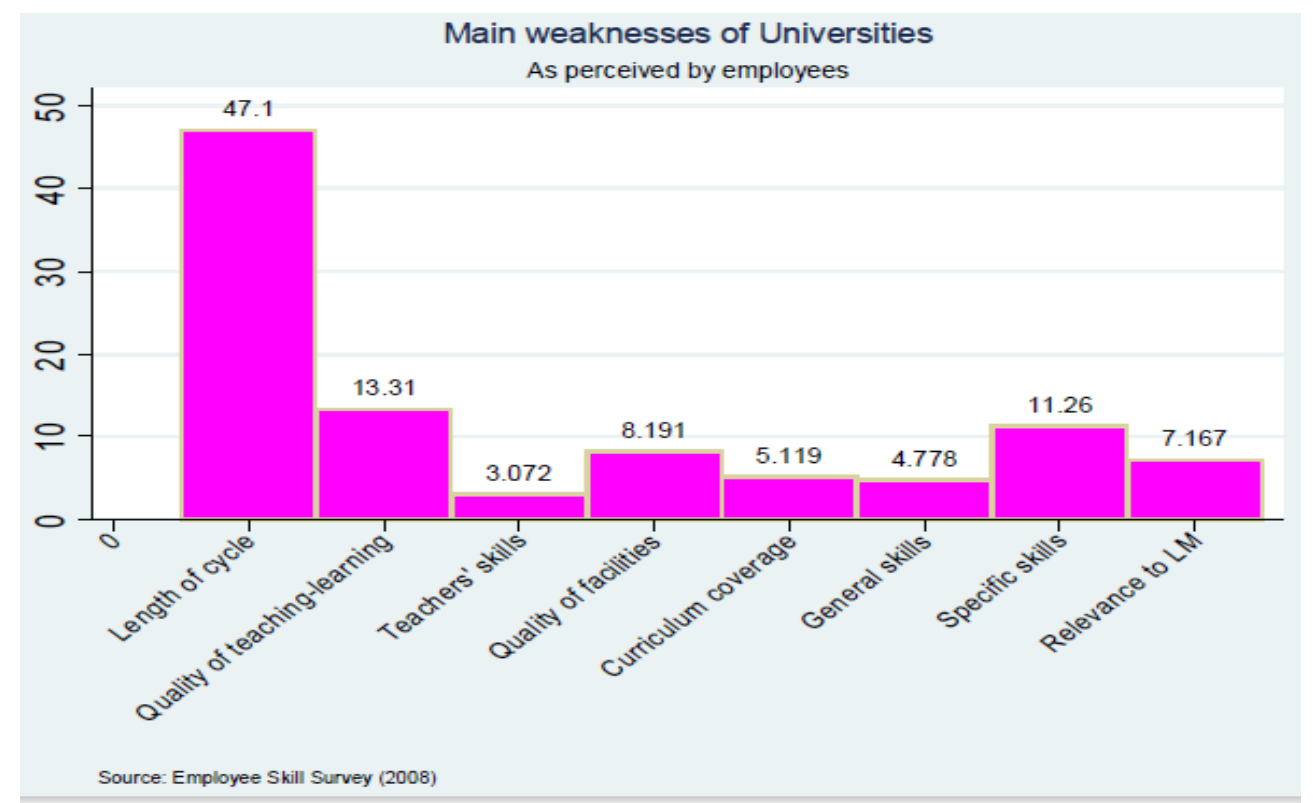

Figure 9. Major weaknesses of universities (employees) 


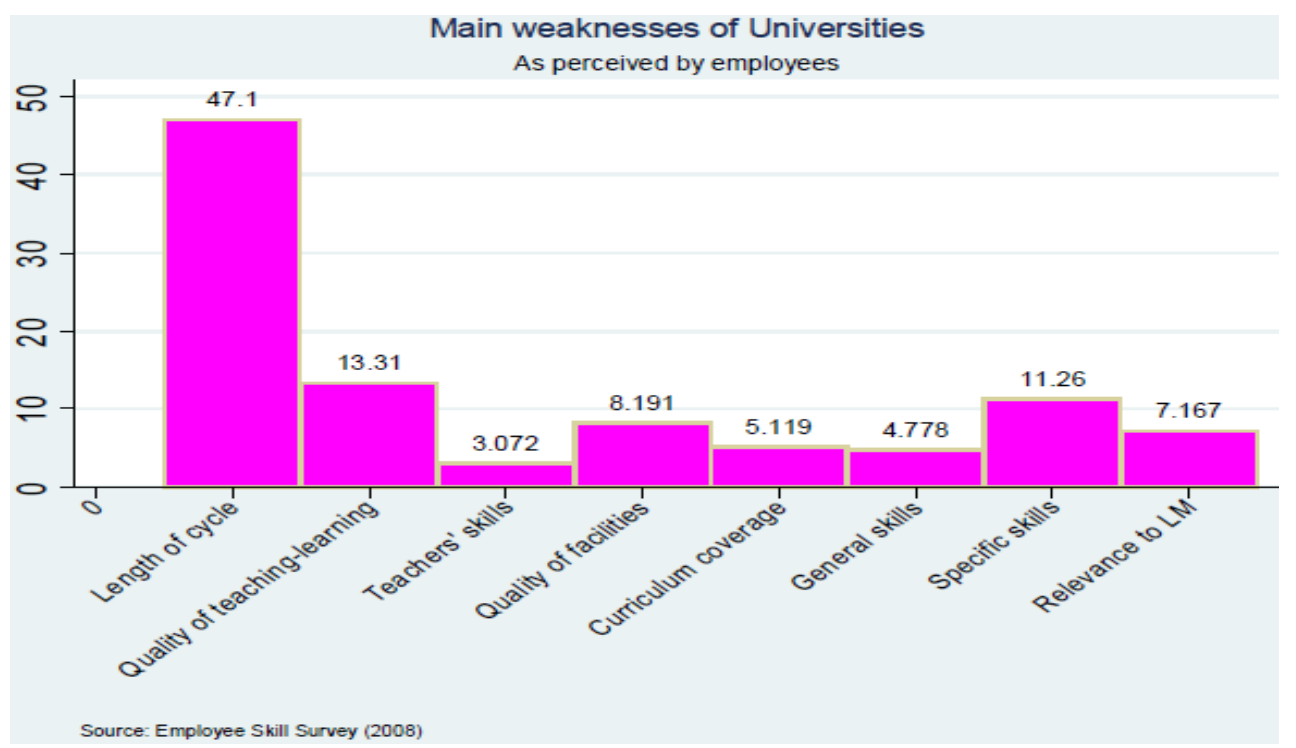

Figure 10. Major weaknesses of diplomas (employees)

According to figure 8,9,10, Practical knowledge is still weak across the board and universities remain quite unconnected from the needs of the labor market judging from rather negative opinions on their capacity to link with industries and adapt to changing labor market needs (Figures 8 and 9). Lack of linkages is likely to be particularly serious in manufacturing given the difficulty that the sector encounters to fill its professional positions. There is an even longer way to go to be able to support innovation through applied research and technology transfer, and the provision of skills for innovation also needs to be improved (judging from the fact that Indonesia lags in all innovation indicators). At the same time, while more connected to labor markets according to employers (Figure 8), diplomas are considered weaker across the board by employees (Figure 10) and in general diploma graduates perform more poorly than university ones on the labor market (according to standard employment indicators), suggesting that curriculum balance, variety and flexibility remain at a premium in higher education in Indonesia and the role and design of diplomas need to be urgently reexamined. Finally, weaknesses are stronger for private tertiary institutions across the board (World Bank, 2010).

From these data, we created an innovation, recommendations and created a useful framework for improving the quality of human resources at the university level. the process is as follows:

Implementation ABEF \& EFQM At University Level

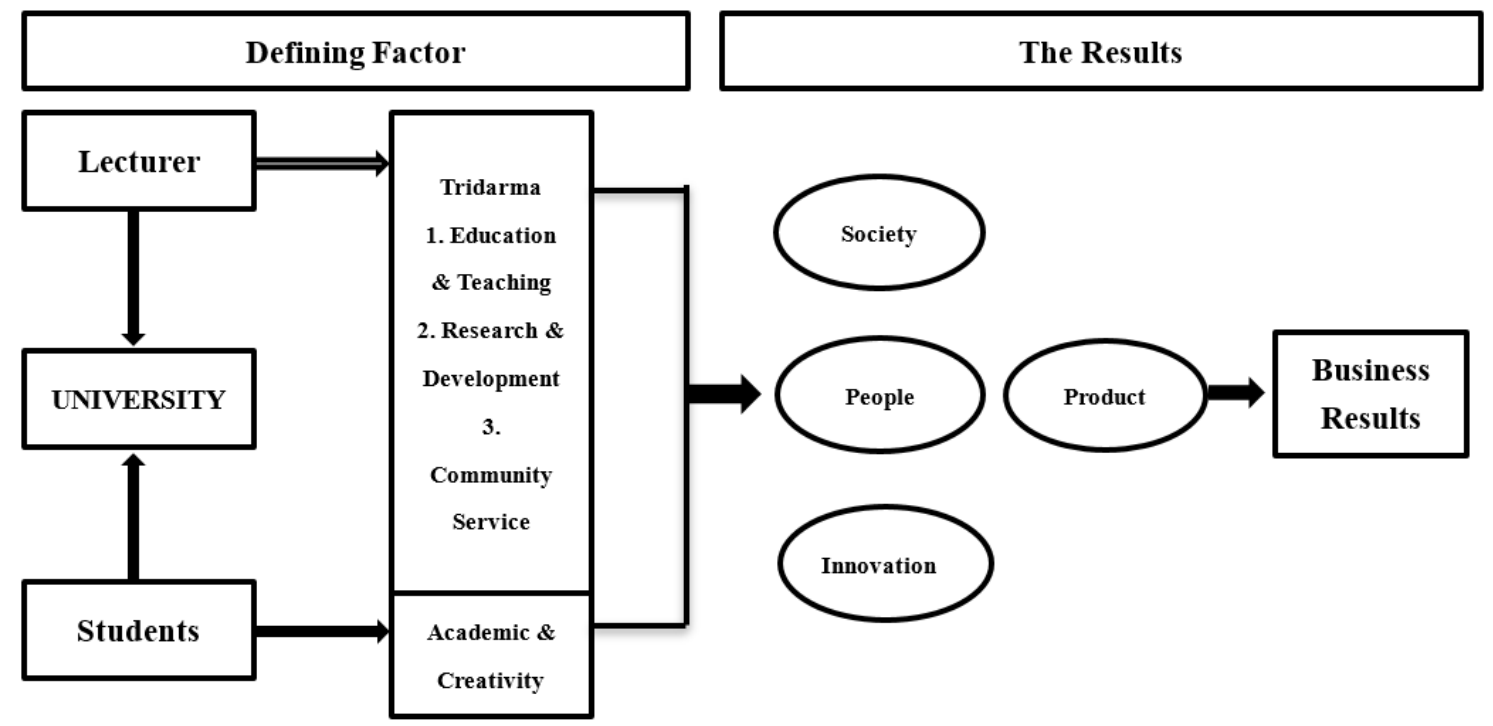

Figure 11. University Quality Award Frameworks [UQAF] 
Framework created from the results of the analysis and experience, and also learns to 2 methods with very details. First, the purpose of the University Quality Award Framework (UQAF) is that universities in Indonesia have a tighter control on-program program contained in the University. Secondly, human resource development should be considered because Indonesia is facing an era of globalization and the ASEAN Economic Community (AEC) in the years 2016-2017. Third, in addition to the information technology is also the basis for improving the quality up to the highest standards.

The framework can be explained as follow:

The first part consists of: Universities - Lecturers - Students. Which then on the faculty contain "Tridarma College", and on the part of the students are "Academic". In this section, university lecturer in the reception must have a strong indicator to accept the lecturer in the University: (1) Lecturer should have a high capacity, high knowledge. (2) The lecturer should also have experience in the areas of focus. Example: A lecturer has the capability of Java programming, but does not have a real experience of what it has, then at the time of teaching, points to the knowledge possessed by both, but if I never do anything to apply what they have, then here if we do assessment, the value of the lecturers will only be assessed 40 . Because it does not have the experience. (1) Lecturers have high Knowledge: 0-40 (Knowledge without experience). (2) Lecturers apply what he had: 0-10 (Practical). (3) Lecturers have experience according to their field: 0-50 (Have Knowledge and Experience). Total: 100. [Example: UQAF Lecturer Level 1: 30 + UQAF Lecturer Level 2: 5 + UQAF Lecturer Level 3: 40: 75] lecturers have scored: 75 points for what he had accomplished. Lodging on the part of students can use the standards already set by each university in Indonesia during the New Student Admission. Special academic, here it takes two specific standards, which is the standard assignment and exam standards. Standard special task Middle Semester Exam - Task 1: Individual/self - Task 2: Group - Final Exam. Special the percentage submitted to the respective lecturers, but here lecturer should do it consistently. Which becomes an important point UQAF is task 1 and task 2. Here the task must have the highest points because here there is a process that must be done by the students. Example: usually when given the task, the students are usually just making an attempt to solve by the time the task would be collected, and therefore to improve the quality, then the points should be lost in total, namely collecting duties when the time is near. UQAF advocate, lecturer giving special points are quite large, where students perform guidance for tasks that are being made, such as guidance Final, facing the minimum 1x per week to the lecturers. Here we will monitor and see whether the students really made his own task and teachers can see how much ability. In the Tri Dharma University, professors are required to be able to create a product that has been patented and used for the community (points 3- Devotion to the public). At other points such as Research \& Development, professors are expected to be able to create new sciences of innovative and creative so that the research is made not only in the form of writing, but writing can be applied and used by the community. On the first point, namely Education \& Teaching, lecturers expected to provide high-quality teaching, that is to say, the lecturer not only provides knowledge but experience to students.

\section{Discussion}

In this section: There is a circle, which is called "The Circle of Innovative University". Inside are four major ways: People, Innovation, Products, and Society which then generate business. First, after doing everything in the first part correctly, it will create a high level of creativity which will produce innovative products. Secondly, the result of the creation of these products will provide revenue to the University and the State, since these products can be sold both at national and international levels.

Nicholas Walterstorff said: "Schools should pay attention a lot more than the knowledge and skills needed to live a life, and trace tendencies students to use their knowledge and abilities in life ... The life to which we are educated is a life filled with gratitude in responsibility, worship, and awards. Then he describes the requirements that allow education as it can grow ... that teachers can teach these concepts through discipline, exemplary and logical thinking ". Walterstorff words true, that education does not merely impart knowledge but to be able to change real life in the future. Looking back first, we observe that education in Indonesia has not been growing very rapidly, but we can already see progress began experiencing major changes, to lead to future higher education and high quality, the education in Indonesia must standardization can be flexibly adapted to changing needs in the current era of globalization. From the analysis using two methods in quality control, then the university innovation is generated as follows: 


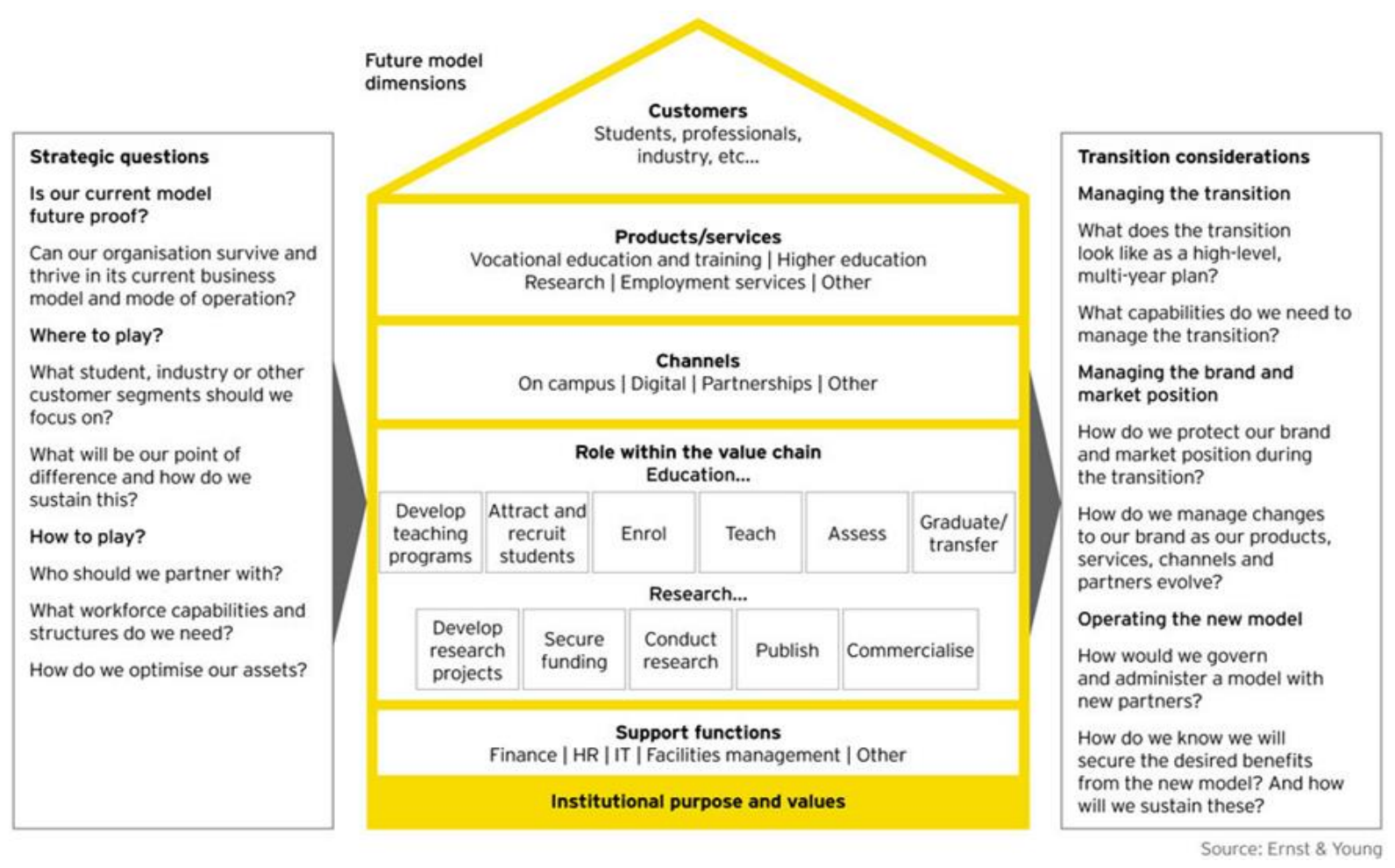

Figure 12. Framework Education Systems From Ernst \& Young Consulting (Young, 2014)

From the picture above we can see there is 3 important processes, and the process in the middle is a crucial process to produce a perfect transformation. The first is the question of strategy, the objectives, and values, and the third is the transition. These three things should not be separated from each other in order to produce a perfect system. In the second part, we can see that the very details to be done, any process for the sake of the process is analyzed in order to generate the appropriate values and goals because our tendency is to want to produce output, but the expense of the process. This should not happen because it would result in instability of a system implementation. Once again we are challenged to reflect on the phrase of Nicholas Wolterstorff who said, "Teaching should be able to answer their needs. Teaching must seek a solution, and the solution must be sought a solution which refers to the students. Teaching should aim to cause an effect, and the effect intended to be an influence on the students. A school curriculum should be determined by reference to what was the target of the curriculum in relation to students. The curriculum should be determined by reference to a conception of when someone is successful to teach the students and when he failed, when targets for pupils has been reached and when has not been reached, when the expected results within the students have been realized and when the results are still far from which are expected. School education must have value and significance is important for students in their lives, both outside and inside the school and education should not only be limited to the need for hours at school. There should be overflowing out, a significant overflow, which is deliberately planned, of life in the classroom to life outside the classroom. Schools should instill valuable virtues for life outside of school as in school. The school itself is not the ultimate goal. People do not get an education at school just for the sake of education in the school itself. People get an education in schools for the sake of life completely. When virtues are implanted school with difficulty it is confined to the classroom, this means that the school has to be irresponsible. Sentence Nicholas W, gives us consciousness absolute, that an education system must be able to change a person's life, not only to fill knowledge to someone, it is appropriate and necessary, not only for consideration, but as a challenge to education in Indonesia, in particular the University of can create a system that is absolutely able to face the challenges of globalization. In this paper, we will try to provide feedback, suggestions, and opinions, which may be applied in our education system today, proposing supplementary or may be considered to repair or simply an addition to the old system that already exists, or if possible to make the system new. The biggest challenge is actually a solid cooperation and awareness to come forward and learn, and that is no less important is a paradigm shift in society and culture that can be collaborated.

University systems in Indonesia-Government-Innovations 


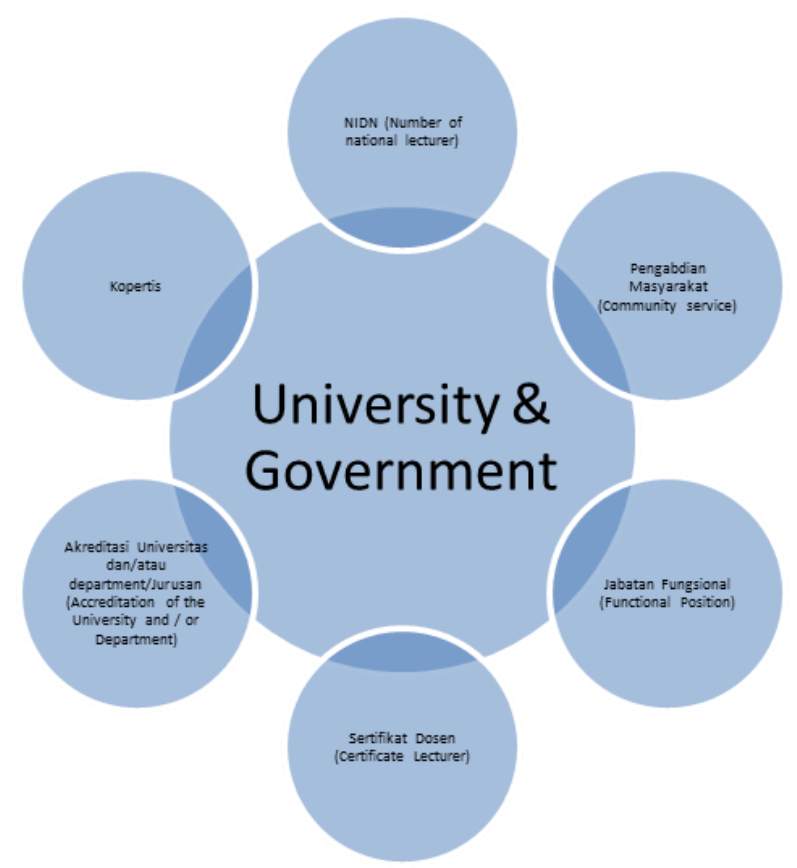

Figure 13. Framework, Relationship between Government and Universities

After reading what was contained on the website owned by the Government, then we can conclude that what is already there, already very good. Here we will only provide suggestions, feedback or our opinion, to develop the quality rather than the resource faculty and enhancing the quality rather than the University in order to compete in today's era of globalization. (A) NIDN (National Number For Lecturer). We, especially those who work in education, knowing that NIDN is essential for every lecturer who works at the University, but until now there are still many obstacles in getting NIDN. This proposal applies only to an honorary lecturer who has worked remained at one of the University and was appointed as a lecturer at the university or faculty that has been appointed as a lecturer at one university. His proposal is as follows: (1) NIDN might be worthwhile if it is integrated with the eID card. (2) National lecturers ID is an e-ID card. (3) Created a special card National Lecturer: Full name; Last title; The name of the university where he worked; Name the last university he got his last title; Place and date of birth; No ID. (4) In this case can cooperate with the Bank so that the card can also function as owned ATM or Credit Card. (5) Charged special administration for the creation of a national lecturer cards, and this applies to the lecturer in question, which can be paid by the university where he worked. (6) If the lecturer is moving work to other universities, then NIDN are already using e-ID will not be a problem, but here will cost special administration by Higher Education for card manufacturing lecturers new national, and fees charged to $2 \mathrm{X}$ instead of cards first, the minimum working in one of the university is 5 years, this is done to minimize lecturer or lecturer shifts like fleas. (B) KOPERTIS, Kopertis in every region of the present, basically is good enough, but a needed improvement of the integrated computerized system, where the system can simplify every university lecturer and click up to date data already owns. Furthermore, all of the system (if possible) based online, and every Kopertis in every region, across Indonesia can open and have the data, so if the lecturer concerned moved, the lecturer can easily change the old data to the new data (In this case, the data conversion, will be charged a special administration to the faculty concerned). For NIDN, the numbering does not change, because it uses the e-ID card. (C) Community Service. Community service must be done by each lecturer and hosted by the University throughout Indonesia, but here sometimes there are issues that arise, as a lecturer, we must know what the problems are surfacing, and that does not come to the surface. This is our proposal: (1) The Government in collaboration with the University to conduct community service changed to the invention; development and implementation of what has been created by the lecturer. (2) The lecturer is obliged to create something useful for the community, not only to hold seminars, training, and workshops and so on, but to create something, be it a product or service which people can use it. (3) Lecturer granted a patent with what has been created, but what has been created to be developed to the maximum, not only $1 \mathrm{x}$ create and then leave it alone. Lecturers are required to maintain the integrity of education with the originality of ideas and create something. (4) After the lecturers obtain patents, here need to be considered, the reward given to the professors, like getting extra money rather than patents, because the product or service is not free, but there are some considerations that deserve we consider here. The proposed division is as follows: $50 \%$ 
Lecturer - 25\% Government - 25\% of the University. (5) Example: In a village or a region there are difficulties in obtaining supplies of electricity, faculty can collaborate with PT. PLN or the private sector to create something in the village or the place, so that people there can obtain and use electricity with alternative technologies that have been created by the lecturer. Surely there is no longer a consideration, if private parties were involved, then the proposed division is as follows: $40 \%$ of lecturers - $20 \%$ government $-20 \%$ of the university - $20 \%$ private. (D) Serdos (Certificate Lecturer), For professors who want to get Serdos, we need to give suggestions for improving the quality of that lecturers get Serdos is a lecturer who really deserve, or perhaps deeper, deserved to have Serdos, so the government does not lose to disburse these funds to lecturers improper, and therefore the funds provided are the result of hard work the people of Indonesia, the only lecturer who has the quality, capability and worthiness that is true, which must accept it. We call the lecturer eligibility standards. His proposal is as follows: (1) Lecturers are required to have a degree or a Ph.D. S3 as a condition to get Serdos. S3 and / or PhD obtained must come from the 10 best universities in Indonesia and / or 20 the best University International level, (2) When professors do not yet have a degree S3 and/or Ph.D., the lecturer shall write journal/research as many as 10 international-Journal, where accreditation A or B and/or 20 Journal / Research national level accreditation. (E) Accreditation of the University and / or the Ministry / Department, For the accreditation of the University and / or department / departments, then points after our analysis, the points raised are considered, just needed a little input and / or proposals to develop, among other things: (1) To get Accreditation, Universities / Departments / Department should be able to provide data that 20 students have been working at the company a minimum international standard for 3 years and 5 years maximum. This data is useful to provide input whether a student / I has managed to develop itself, the result rather than the university education. Here it is necessary to build an advanced system for the alumni who can build good relationships with the alumni, (2) To Accreditation B, University / Department / Department should be able to provide data that 15 students have worked at the company for international, (3) Accreditation C, University / Department / Department should be able to provide data that 10 people had been working in the company in national level, rank 1-10 of the best companies in Indonesia. (F) Functional . Special functional position, there are several entries in order to be more effective and efficient, among others: (1) Assistant Expert (minimum requirement S2), (2) Associate Professor (S3 minimum requirements or is taking studies S3), (3) Associate Professor head (condition S3), (3) Professor (S3/pHD terms and 10 International Journal of accreditation). ** Elements of $\mathrm{A}, \mathrm{B}, \mathrm{C}$ and so removed. Here we can provide the question, why should be eliminated, because this does not make a better system. The most important thing here is that the point's most important points there are achievements made by the lecturer, achievements that can provide a big change in society.

\section{New Framework To Produce The Best University}

In this section, we will provide inputs, especially for improving the quality of the lecturers at the university level. This is the beginning of a real improvement of the quality of education. First of all, we must be able to define in advance, who is called as the "consumer" within the University ? Here, there are a lot of debate and notion regarding of the terms "consumer" in the world of education, especially university. We define simply as, "Consumers can be divided into two essential parts, namely internal consumers and external consumer, which means that faculty and students at the university are consumers and consumers who are outside of the university". Whether this can be explained more in-depth ? The answer is "yes", but with a separate study from the topic that we discuss today. We go back to the original topic, after we provide feedback and opinions to the government's existing systems, especially in the world of education at the university level, then the resulting educational framework illustrate as follows:

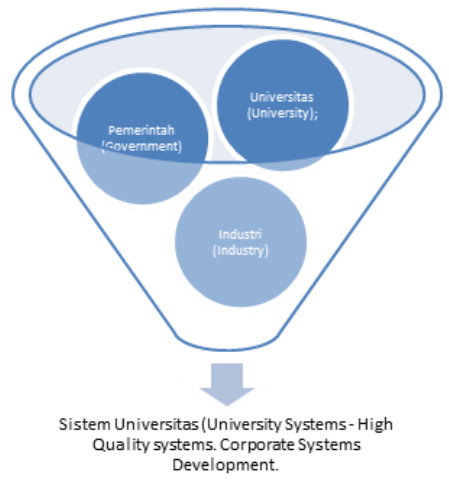

Figure 14. Relationship between government-university-Industry: Produce sophisticated systems and human resources is very high 
From Figure 14, we know that solid cooperation between the Public-university-industry will be able to produce an integrated system that can produce high quality of human resources. Furthermore, this development will be able to change some things in culture and paradigms in society. Is it ? Yes, because with a clear system it would able to form a habit and provide a fixed pattern in the paradigm so that change will be possible as long as the "old habits" changed first.

From what have been described, then we can put forward a framework as follows:

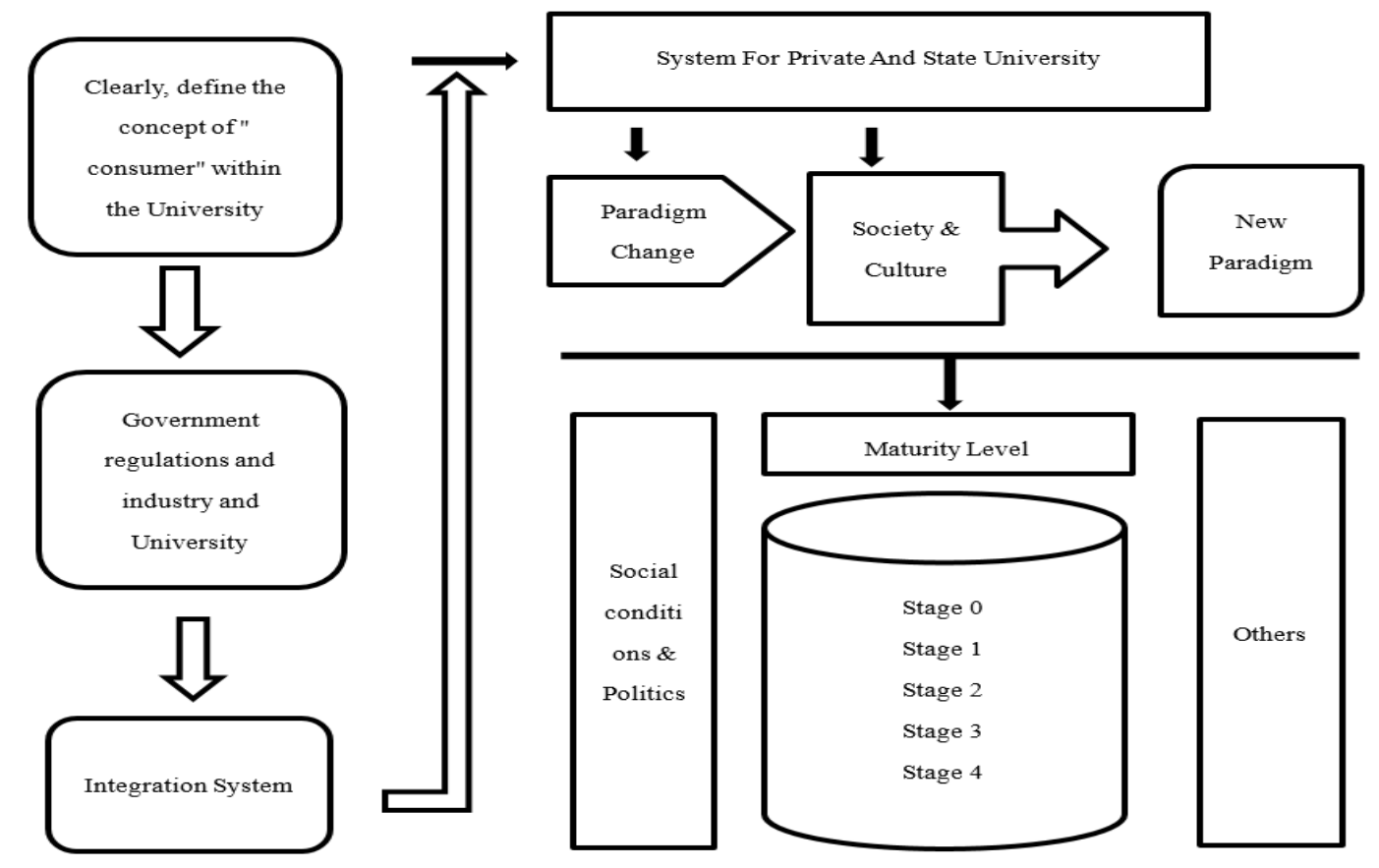

Figure 15. University Systems Life Cycle Framework

University Systems Life Cycle Framework, this can be explained by looking at indicators of what is contained in follows: (1) Level 0-The absence of a system; All done manually; There is no cooperation between the Government-University-Industry. (2) Level 1-The system wakes; There are still using manual systems and technology 70\% 30\%; Cooperation still has not woken up properly; Development of human resources is still lacking; There are many application systems that overlaps and confusing; Operations are still moving slowly and do not run effectively and efficiently; Poor documentation of the data, so a lot of important data that is not stored and may be lost. (3) Level 2-System woke up fairly well; Process data began to improve; Use of information technology significantly; Applications that do not overlap and easy to use by developing existing version; Good operational; Good documentation; The process of human resources development and training were quite good; The creation of local products that can be used by the public. (4) Level 3- System between the GovernmentUniversity woke up well; System between the Government-Industry developed well; System between the Government-University-Industry integrated; Shifting paradigm began to be built in the community; Rules can be defined clearly, accurately and not confusing; Documentation, operation and supervision of the goods; Good cooperation, decentralization, integration of surveillance systems; The creation of local products that become worldwide. (5) Level 4- System of Government-Industry-University has been running very well; Documentation of data has been conducted very neatly; Operation, control and excellent cooperation; Team formed a very solid for each section; Cooperation between industry and universities run consistently, especially in the research \& development; Can reach the international level, the creation of local quality products that can be global; The paradigm shifts in society, especially for the concept of education. In this, we can see very clearly, the key is that human resources must be ready to run all of this. Without the readiness of human resources, then this will hinder the development of system's construction. We need to remind clearly, which is an important process that must be considered and thought out very well in order to create effective systems of integration and efficiency.

Stages that can be applied and combined, coming from the World Bank, can be explained as follows:

Five general skill related to priorities can be highlighted for Indonesia: 
First of all, the country needs to improve skill measurement to get a fuller understanding of needed skill and the gaps. Following the example of this report, Indonesia needs to get better understanding of what skills are needed and what skills are lacking. Both demand and supply-side sources could be used to undertake this diagnostic, ranging from employer/employee skill surveys (which can simply be integrated within existing firm surveys), and better/more use for firm and tracer surveys, to participate in adult competency tests.

Second, it is urgent for Indonesia to address the still unsatisfactory quality and relevance of its formal education. More than quantity, quality and relevance are the critical issue for the formal education and training sector in Indonesia. Improvements are needed at all levels to improve quality of the teaching-learning process, also to strengthen linkages with firms. It is particularly imperative for secondary education to improve in order to provide the Indonesian youth with skills that they will need on the labor market and to improve their labor market outcomes.

Third, the country needs to set-up multiple pathways for skill development. Beyond the quality and relevance of its formal education, Indonesia need to continue building skill development system which creates opportunities for complementing existing skills, updating skills in time and providing skills outside of the school and/or vulnerable youth and adults. While the development of a national qualification framework, which provides much needed articulation, is a promising step in that direction, this framework needs to be further strengthened (including institution accreditation, skill standardization, certification, and regulating bodies) also importantly, the constraints to build a multipurpose system need to be fully understood and appropriate actions identified to address them. There is a need for instance to strengthen institutional and funding incentives for life long learning, including providing incentives to firms for also fulfilling a longer-term training role. At the same time, it is imperative to asses more fully and rigorously outcomes of the existing non-formal education, training institutions, programs and their potentials as provider to relevant skills for vulnerable youth and adults, complementary skills and in time skill development.

Fourth, the country needs to develop an integrated approach to tackle skill development for youth. In spite of increased educational attainment, youth skills are insufficient in Indonesia and contribute poorly to labor market outcomes. An integrated approach is needed, including to improve formal education (particularly secondary one), further development and improving the non-formal "second-chance" programs, building more bridges between education and labor market through school to work transition programs in providing labor market information, placement and complementary life - technical skills, also focusing firms' training role for youth on complementary job specific skills.

Fifth, Indonesia should also tackle labor market constraints which affect the skill matching process. A diagnostic of labor market constraints is necessary to complement a skill supply-demand one to get a broader view of skill that matches the constraints and to make sure that inefficiencies are being minimized. For instance, even if skill supply is greatly improved, lack of diversification of recruitment practices could still constrain the skill-matching process in Indonesia. Labor market segmentation issues should also be closely examined (World Bank, 2010).

\section{Conclusion \& Recommendation}

After doing this research and doing in-depth analysis so as to create the innovative university, it can be concluded and recommended as follows:

1. Quality is the most important thing and should be getting more attention in improving human resource capacity to face globalization and the ASEAN Economic Community (AEC). In this case, University is one sector that urgently need to get more attention than the government at this time. The University can apply more than one methods that have been recommended, namely the Australian Business Excellence Framework (ABEF) and the European Foundation for Quality Management (EFQM). Why? Both of these methods can be used as basis for the international community that look up at the level where the university in terms of quality. Moreover, Framework derived from Ernst \& Young can be used to develop the system, the rules and provide useful input for education, especially university. The need for the development of an integrated system between the Government-UniversityIndustry in order to create local products with a quality that can compete with the globalization.

2. The University need to increase programs that have been held in order to deal with the ASEAN Economic Community (AEC) and here required a quality model to be able in achieving high quality. In this study, the University Quality Award Framework is a quality method for developing university's quality level; For the University Quality Award Framework (UQAF) required further development of the indicators. Example: each university has a culturally appropriate indicator inside this university. For this certain matter, it needs an absolute standard stipulation for indicator. Furthermore, Development of human resources is absolutely necessary because it is central to the development of the next. Socialization needed in order to change the paradigm of society, especially for education in family and society. 
3. The University need to improve its professors into professors that have the ability not only to focus on the degree and knowledge but also focus on the experience, namely the application rather than what he already has, Indonesia needs to change some of the basic cultures that might becoming a problem later on. Culture should not become a barrier to improving quality. Why can culture be an obstacle? For if there are some habits that do not conform to the quality standards, then these habits must be removed, especially if not providing any benefit to the community. Whether this can be said to be too authoritarian? The answer is no! Due to obtain a high quality, it would require some significant changes in order to achieve the highest levels of quality. Moreover, revise the rules that already existed today, by defining in advance the meaning of "consumer" within the university level. Building a betterintegrated system, between the Government-Industry-University, where the system can assist the development and creation of an outcome that can be useful for communities and local products to become worldwide. The need for cooperation with industries to international levels should help to promote creative ideas within the University. Increased exchange of students and professors at the University at international level by focusing on partnershipbased research \& development in creating products.

\section{References}

Agasisti, T., \& Catalano, G. (2006). Governance Models of University Systems-Toward Quasi Markets? Tendencies and Perspectives: A Eropean Comparison. Journal of Higher Education Policy and Management, 28(3), 245-262. https://doi.org/10.1080/13600800600980056

Alter, S. (2008, J). Defining Information System as Work Systems: Implications for the IS Field. European Journal of Information Systems, 17(5), 448-469. https://doi.org/10.1057/ejis.2008.37

Bhardwaj, M., \& Singh, A. J. (2011). Automated Integrated University Examination System. Himachal Pradesh University Journal, 1-10.

Erna Iftanti. (2012). A Survey of the English Reading Habits of EFL Students in Indonesia. TEFLIN Journal, 23(2), 149-164. Retrieved from https://doi.org/10.15639/TEFLINJOURNAL.V23I2/149-164

Ernst \& Young. (2014, September 29). Higher Education-Looking Forward; An Educator's Perspective: A thousand year old industry on the cusp of profound change. 21st Century Universities: Performance and Sustainability IUA Symposium, Dublin. Retrieved from http://slideplayer.com/slide/2812265/

Ernst \& Young. (2018). Can the Universities of Today Lead Learning for Tomorrow?: The University of the Future. Retrieved from https://www.ey.com/au/en/industries/government---public-sector/ey-university-of-thefuture-2030

Hasan, M., \& Hannifah, H. (2013, March). A Study of Australian Business Excellence Award Winners. Journal of Service Science \& MAnagement, 6(1), 31-37. https://doi.org/10.4236/jssm.2013.61004

Hegarty, N. (2014). Where We Are Now-The Presence and Importance of International Students to Universities in the United States. Journal of International Students, 4(3), 223-235.

Jalal, F., \& Sardjunani, N. (2005). Increasing Literacy in Indonesia.

Llusar, B., Tena, E., A., B., Roca-Puig, V., \& Beltran-Martin, I. (2009). An Empirical Assessment of the EFQM Excellence Model: Evaluarion as a TQM Framework Relative to The MBNQA Model. Journal of Operation Management, 27(1), 1-22. https://doi.org/10.1016/j.jom.2008.04.001

Megawati Santoso. (2013). Indonesian Qualifications Framework.

Mohammad, M., Mann, R., Grigg, N., \& Wagner, J. P. (2011). Business Excellence Model: An Overarching Framework for Managing and Aligning Multiple Organisational Improvement Initiatives. Total Quality Management \& Business Excellence, 22(11), 1-40. https://doi.org/10.1080/14783363.2011.624774

Pratikna, R. N., \& Gamayanto, I. (2017). Developing Leadership Systems Inside University using Jim Collins Method [Good to Great]: People Management Development to Face ASEAN Economic Community in Indonesia. Review of Integrative Business and Economics Research, 6(3), 45-55.

SAI. (2004, March). The Australian Business Excellence Frame Work . SAI Global Limited.

Suryaman. (2018). Indonesian Private University Lecturer Performance Improvement Model to Improve a Sustainable Organization Performance. International Journal of Highee Education, 7(1), 59-68. https://doi.org/10.5430/ijhe.v7nlp59

World Bank. (2010). INDONESIA SKILLS REPORT - Trends in Skills Demand, Gaps, and Supply in Indonesia. World Bank. 


\section{Copyrights}

Copyright for this article is retained by the author(s), with first publication rights granted to the journal.

This is an open-access article distributed under the terms and conditions of the Creative Commons Attribution license (http://creativecommons.org/licenses/by/4.0/). 